\title{
Community involvement in reproductive health: Findings from research in Karnataka, India
}

Foundation for Research in Health Systems

Follow this and additional works at: https://knowledgecommons.popcouncil.org/departments_sbsr-rh

Part of the Family, Life Course, and Society Commons, International Public Health Commons, and the Maternal and Child Health Commons

How does access to this work benefit you? Let us know!

\section{Recommended Citation}

Foundation for Research in Health Systems. 2004. "Community involvement in reproductive health: Findings from research in Karnataka, India," FRONTIERS Final Report. Washington, DC: Population Council. 


\section{Community Involvement in Reproductive Health: Findings from Research in Karnataka, India}

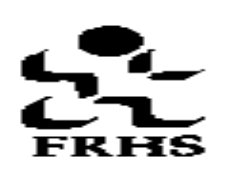

Foundation for Research in Health Systems

\section{September 2004}

This study was funded by the U.S. AGENCY FOR INTERNATIONAL DEVELOPMENT (USAID) under the terms of Cooperative Agreement Number HRNA-00-98-00012-00 and Population Council Subagreement Number AI00.49A. The opinions expressed herein are those of the author and do not necessarily reflect the views of USAID. 


\section{CONTENTS}

List of Tables and Figures...........................................................

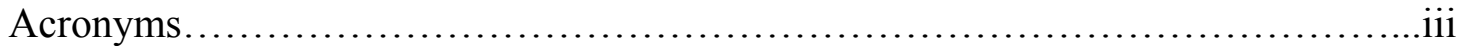

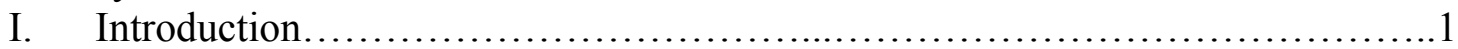

II. Process of Health Committee Formation..........................................

III. Performance of Health Committees.............................................. 12

IV. The Impact of the Committee.............................................. 15

V. Committee's Style of Functioning...................................... 19

VI. Factors Contributing to the Effectiveness of the Committee Model...............23

VII. Sustaining and Scaling Up the Committee Model...............................26

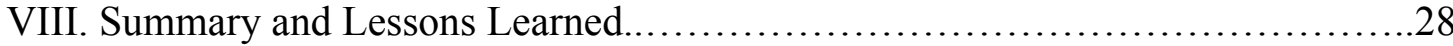

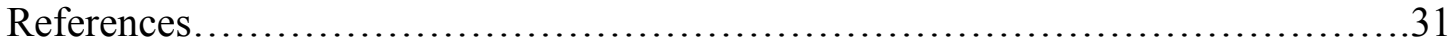

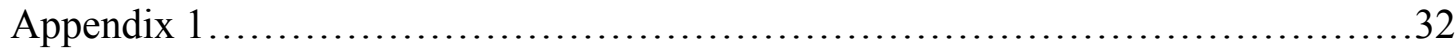

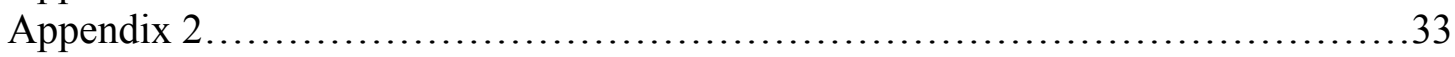




\section{LIST OF TABLES AND FIGURES}

Table 1. Performance on reproductive and child health indicators....................6

Table 2. Committee performance by method of formation......................... 9

Table 3. List of programs carried out by committees as of June $2002 \ldots \ldots \ldots \ldots \ldots \ldots \ldots$

Table 4. Activity level of committees by programs, attendance and expenditure........17

Table 5. Participation and knowledge about committee by household characteristics...17

Table 6. Status of outcome on reproductive and child health indicators.................21

Table 7. Percent changes in the "before" and "after" measures of outcome indicators...23

Box 1. List of process and outcome indicators.................................... 16

Box 2. Illustrations of committees mobilizing resources............................ 18

Box 3. An illustration of networking capacity.................................. 19

Figure 1. Dimensions of committees' functioning style..........................20 


\section{ACRONYMS}

$\begin{array}{ll}\text { ARI } & \text { Acute Respiratory Infections } \\ \text { ANC } & \text { Antenatal Care } \\ \text { BPL } & \text { Below Poverty Line } \\ \text { CNAA } & \text { Community Needs Assessment Approach } \\ \text { FRHS } & \text { Foundation for Research in Health Systems } \\ \text { ICPD } & \text { International Conference on Population and Development } \\ \text { IFA } & \text { Iron-Folic Acid } \\ \text { NGO } & \text { Nongovernmental Organization } \\ \text { ORS } & \text { Oral Rehydration Salts } \\ \text { PHC } & \text { Primary Health Centre } \\ \text { RCH } & \text { Reproductive and Child Health Services } \\ \text { RTI } & \text { Reproductive Tract Infection } \\ \text { STI } & \text { Sexually Transmitted Infection } \\ \text { TT } & \text { Tetanus Toxoid }\end{array}$

Community Involvement in Reproductive Health:

Findings from Research in Karnataka, India

iii 


\section{INTRODUCTION}

In April 1996, the government of India decided to provide a package of reproductive and child health services through the existing family welfare program. ${ }^{1}$ To deliver these services, the government adopted a community needs assessment approach (CNAA) based on the principles of the International Conference on Population and Development (ICPD). ICPD recognizes women's right to reproduce and regulate their fertility, go through pregnancy and childbirth safely, and have sexual relations free from fear of pregnancy and disease. ${ }^{2}$

To implement this approach, the government abolished its 30-year old practice of setting contraceptive targets centrally and introduced a decentralized planning strategy. Health workers assessed the reproductive health needs of women in their respective areas and prepared local plans to meet those needs. They were also charged with involving community leaders to promote community participation in the reproductive and child health program. ${ }^{3}$

Since early 1998, several evaluation studies have assessed the impact of the CNAA on the program's performance and on community participation. These studies showed that the performance of the maternal health care program improved, whereas the functioning of the family planning program initially declined but later recovered. Health workers were relieved of the pressure of reaching specific targets so they could give more attention to new reproductive health services. However, the approach achieved little in boosting community involvement in the program. ${ }^{4}$ Although the government provided guidelines to local health staff on how to involve the community in decentralized planning, it did not insist that the guidelines be implemented. In addition, there was no incentive for community leaders to get involved in the planning exercise because funds were not transferred to their level. ${ }^{5}$ The health staff were not keen to involve community leaders because they feared that they would interfere in their work. ${ }^{6}$

\section{Past Experiences of Community Involvement in Health Programs}

In India, there are three well-known examples of involving the community in health programs: the Community-Based Distribution project, the Community Health Volunteer scheme, and the Link Worker scheme. In all three schemes, community involvement meant appointment of one volunteer per village, who was selected either by village leaders or by health officers. Volunteers received an honorarium or an incentive from the government, and in return, they performed certain tasks assigned to them. Many of them considered themselves village-level government functionaries.

In the Community-Based Distribution project, village health committees selected organizers to function as depot holders, mainly for contraceptive methods. They received free supplies of contraceptives from the government, which they sold for a small price. This profit provided them with an incentive to work as organizers.

Community Involvement in Reproductive Health:

Findings from Research in Karnataka, India 
In the Community Health Volunteer scheme, which was introduced in 1977, village leaders selected health volunteers from within villages. The government provided them with training, medicine kits, and a small monthly honorarium. Community health volunteers provided treatment for minor ailments and counseled couples about contraceptive methods. This scheme ended in 1983 when volunteers started demanding to be employed by the government.

In the Link Worker scheme, the government appointed volunteer couples from among villagers and paid them a small honorarium to function as contraceptive depot holders. They promoted contraceptive use in their communities as long as the government paid them the fee.

Besides these government schemes, most nongovernmental organizations have developed models of community involvement in their health programs. They also pay honoraria to village-level volunteers but ensure that the community selects them and that volunteers receive adequate training to build their capacity and confidence in dealing with the community's health needs.

Some states created other mechanisms to involve communities such as women's health groups and village health committees. One notable mechanism has been the People's Plan model in Kerala. It engaged the community in identifying development issues in their area, making decisions about resource allocations, and carrying out social audits of development programs. Two distinguishing features of this mechanism were: 1) transfer of 35 to 40 percent of state funds to local self-government, and 2) development of clear project formulation and resource allocation guidelines to help curb misuse of funds by local parties with vested interests. ${ }^{8}$ Villages' elite members often dominate mechanisms such as village health committees, women's health groups, and health advisory committees. In the Kerala model, their roles have focused on mobilizing people and providing them with support during Pulse Polio and family planning campaigns. ${ }^{9}$ Health staff use these committees to spread health messages more often than to plan or monitor health delivery services.

\section{Project Background}

Under the India Population Project-IX (1997-2002), the government of Karnataka tried to form sub-centre health advisory committees to promote community participation in the health and family welfare program. Each of these committees consisted of eight to ten members, with a local government leader serving as president and a female health worker acting as member secretary. Other members of these committees were nutrition workers appointed under the Integrated Child Development Scheme, local doctors, and prominent women from the community. The state government directed female health workers to form these committees and provided them with 200 rupees (Rs.) per month (approximately US\$4) to cover their meeting expenses. Despite this directive, most health workers had not formed committees or activated existing ones because they saw no role for them. However, the state government was keen to revisit decentralized 
planning and activate as many health committees as possible to support the reproductive and child health program.

The Foundation for Research in Health Systems (FRHS), a nongovernmental organization working in health systems research, was also interested in finding effective ways to involve communities in the decentralized reproductive and child health program. Therefore, FRHS decided to carry out an operations research project in the Hunsur block of Mysore District in Karnataka to pilot test a health committee concept. From July 2000 to June 2002, FRHS formulated and implemented the project concept in collaboration with the state health department. The Population Council's Frontiers in Reproductive Health program funded the project as part of its Small Grants initiative.

Mysore District is located about $200 \mathrm{~km}$ from Bangalore City in the southernmost part of Karnataka, a progressive state in southern India. Its population is about 2.6 million, which is divided into seven blocks (the smallest administrative unit in rural India); one of these is Hunsur. This block has 216 villages and a population of about 258,000. It has 14 primary health centres and 70 sub-centres, 64 of which are rural and six urban. The state reproductive and child health officer selected Hunsur as the experimental block for this project because it is the largest one in the district and its reproductive and child health service has performed poorly. This block also represents a mix of tribal and non-tribal populations, irrigated and non-irrigated areas, and different economic levels.

Hunsur town is well connected to Mysore City by road. Government buses ply this route frequently, although 25 percent of the villages in the block are not connected to this route. Hunsur town is situated on the state highway that links Karnataka to the neighbouring state of Kerala. It is close to the Nagarahole National Park, a major tourist attraction. The block has a Tibetan refugee settlement spread over five of its 64 rural subcentres. These refugees live in small settlements, called haadis, away from the main villages.

The project design required researchers to select a comparison block similar to the experimental block with respect to socioeconomic conditions and reproductive and child health indicators, but not adjacent to the experimental block. The reproductive and child health officer suggested using Narsipur as a comparison block because it fulfilled most of those conditions. It was similar in size and population composition to Hunsur, but had somewhat better reproductive and child health indicators because an NGO had been working in the area under a project funded by the World Health Organisation to promote community participation using rapid rural appraisal methodology. By using Narsipur as a comparison block, the state government hoped to find out which approach worked better to promote community involvement and improve reproductive and child health performance. Researchers used "before" and "after" measurements from the experimental and comparison blocks. 


\section{Description of the New Committee Model}

Most elements of the new health committee model were chosen in consultation with health staff from Hunsur, active female government leaders, local NGOs, and representatives of selected community-based organizations such as youth groups and mothers' health groups. At the start of the project, FRHS convened a one-day meeting to discuss the objectives of the experiment and to seek suggestions about the health committee concept. In this meeting, health staff voiced apprehensions about the project and its chances of success. As expected, community leaders were largely supportive of the idea. The two groups discussed what might work and what might not, and concluded that health committees would work if:

- Members are selected by the community and not by government staff

- They have both men and women and caste representation

- They are provided seed money to facilitate start-up activities

- They have help, at least initially, to decide what to do or not to do

FRHS accepted all of these recommendations and designed the committee structure, the formation process, and the committee's role as described below:

\section{Committee structure}

- Health committees were formed at the sub-centre level with representation from all constituent villages.

- Each member represented a cluster of 50 to 60 households in a village.

- Each committee was expected to have at least 50 percent female members.

- Committee members selected their president and secretary from among the group.

- Health workers, community nutrition workers, and village council members were invited to attend committee meetings but had no formal role like the president, secretary, or treasurer in the committee.

\section{Formation process}

- Health staff used village maps to first identify clusters of households of different castes and communities.

- From each cluster of 50 to 60 households, health staff suggested potential candidates for the health committee.

- The list was approved and finalized by calling village meetings that were attended by all adults.

\section{Committee role}

- Committees were to undertake activities to create health awareness about existing and new health services.

- Members were to participate in identifying people's health needs and developing activity plans.

- Committees were expected to foster trust and understanding between community members and health staff. 
To implement this model and to help it function, FRHS appointed seven community facilitators in the project block, at the rate of one for every two primary health centres. The facilitators helped form health committees, trained members in their roles and responsibilities, and guided them in fulfilling their roles.

\section{Process of Health Committee Formation}

This section describes the formation of 64 health committees that covered all rural subhealth centres in the experimental block, Hunsur. Implementation of the project began with a baseline survey in the experimental and comparison blocks. After the survey, the community facilitators initiated the process of forming health committees, giving them guidance, and providing them with certain inputs to help them function.

\section{Baseline Survey}

At the start of the project, a household survey was carried out to gather baseline data on awareness and utilization of reproductive and child health services in the Hunsur and Narsipur blocks. The sample consisted of 1,000 randomly selected women of reproductive age, chosen from 30 villages. This sampling technique and a similar survey instrument were used in reproductive and child health surveys carried out by the International Institute of Population Studies. The major findings of this survey showed that service coverage in the experimental block was reasonably high for most services, but that indicators of quality of care were low.

- The contraceptive acceptance in the block was high (72\%), but about one-third of acceptors reported suffering from contraceptive side effects.

- Almost all pregnant women received antenatal care (ANC) but less than one-third of them received "full care," which consisted of three ANC visits, tetanus toxoid (TT) vaccinations, and iron-folic acid tablets (IFA).

- Over 60 percent of deliveries took place at home, with trained professionals attending fewer than 10 percent of them.

- About one in four women reported suffering from at least one symptom of a reproductive tract infection (RTI), but less than one-third sought treatment.

- More than half of the women had heard about HIV/AIDS but did not know what caused it or how to prevent it.

- The rate of child immunization was high but the practice of immediate breastfeeding was low (31\%).

- Only one in five babies were weighed at birth, and fewer than half of mothers knew about giving oral rehydration salts (ORS) to children with diarrhoea.

Data from the experimental block, relative to the comparison block, showed significant differences on a few indicators: contraceptive side effects, institutional deliveries, and women's knowledge of ORS. Researchers also compared the Hunsur data with data from the Mysore District and the Karnataka State reproductive and child health survey, which

Community Involvement in Reproductive Health:

Findings from Research in Karnataka, India 
was conducted about a year before the baseline survey of this project. This comparison supports the reproductive and child health officer's claim that Hunsur was a below average block of Mysore District and Karnataka State on six out of 12 critical reproductive and child health indicators identified by the government (see Table 1).

Table 1: Performance on reproductive and child health indicators

\begin{tabular}{|l|c|c|c|c|}
\hline \multicolumn{1}{|c|}{ Indicators } & $\begin{array}{c}\text { Hunsur } \\
\mathbf{N = 1 0 5 7}\end{array}$ & $\begin{array}{c}\text { Percent } \\
\text { Narsipur } \\
\mathbf{N = 1 0 4 8}\end{array}$ & $\begin{array}{c}\text { Mysore } \\
\text { District }\end{array}$ & $\begin{array}{c}\text { Karnataka } \\
\text { State }\end{array}$ \\
\hline 1. Couples using family planning method & $\mathbf{7 2}$ & 67 & 65 & 58 \\
\hline 2. Reported contraceptive side effects & 34 & 17 & 11 & 16 \\
\hline 3. Pregnant women sought antenatal care & 95 & 98 & 95 & 89 \\
\hline 4. Received 3 ANC visits+ TT+ IFA & 74 & 85 & 76 & 60 \\
\hline 5. Institutional deliveries & 34 & 50 & 60 & 50 \\
\hline $\begin{array}{l}\text { 6. Deliveries attended by health } \\
\text { professionals (safe deliveries) }\end{array}$ & 40 & 56 & 65 & 60 \\
\hline 7. Sought treatment for RTI & 33 & 30 & 51 & 54 \\
\hline 8. Women had heard about HIVIAIDS & 62 & 70 & 53 & 61 \\
\hline 9. Reported immediate breastfeeding & 32 & 15 & 37 & 32 \\
\hline 10. Babies weighed at birth & 21 & 34 & 48 & 43 \\
\hline $\begin{array}{l}\text { 11. Mothers knew about giving ORS to } \\
\text { children with diarrhoea }\end{array}$ & 47 & 19 & 41 & 38 \\
\hline 12. Children fully immunized & 96 & 97 & 93 & 72 \\
\hline
\end{tabular}

Data from this survey were used not only to assess the health committee's impact at the end of the project, but also to help committees to decide what types of health activities they should undertake.

\section{Health Committee Formation}

After the baseline survey was completed, the community facilitators began the process of forming committees. Health workers mapped out all villages and identified clusters of 50 to 60 households that belonged to various castes and communities. Health workers who had worked in the villages for two years were also able to identify candidates for the health committees from each cluster. New workers, however, consulted with community nutrition workers to select candidates. Health workers were then supposed to obtain approval for the candidate list during a village council meeting; however, they did not feel comfortable calling a meeting for this purpose. Instead, they approached local government leaders with their candidate lists to seek their approval.

Unfortunately, in a few cases, the local leaders did not approve all of the candidates and suggested other names, which the health workers did not accept. Occasionally, arguments over who should decide upon health committee membership occurred. Health workers thought they should select members because they would be the ones to work with committees, while leaders wanted the final say because they felt they knew what was best for their people. Researchers decided to resolve this issue through an experiment. Out of seven primary health centres selected to implement the first phase of the project, they 
assigned three centres to the council meeting method, two to the health worker method, and two to the local government method for selecting committee members.

The council meeting method involved calling meetings in which community facilitators and health supervisors informed people about the project and the role of health committees. People then suggested names of individuals from different clusters for committee membership. If those individuals were present at the meeting, they provided their consent. These meetings typically lasted for two hours. However, it took over three months and scheduling over 80 meetings to form 16 committees. Scheduled meetings were often postponed due to weddings, funerals or festivals. This method also required a substantial amount of the community facilitators' time. Leaders would call council meetings only if the facilitators requested them. They had to be present at all council meetings and spent three hours each time waiting for people to arrive.

The health worker method involved health workers listing potential committee members and then finalizing the list by consulting a few formal and informal village leaders. Workers usually tried to accommodate the changes that leaders suggested, but the changes rarely occurred. This method was efficient; workers formed nine committees within one month without making any demands on the community facilitators' time.

The local government method involved community facilitators informing government members about the project and then requesting them to nominate members to health committees from each cluster of 50 to 60 houses. Typically, the local leaders asked the facilitators to come back for the lists later so that they could consult with other people. Using this method took about two months to form 11 committees because leaders were either busy or not available when the facilitators visited them.

After these committees had worked together for six months, researchers evaluated how well they functioned, using three criteria: 1) members' acceptance in the community, 2) members' profile, and 3) committees' performance. This evaluation showed that:

- Members' acceptance was equally high in committees formed through the village council meeting and the health worker methods, but was relatively low in committees formed by the local government method.

- The village council meeting method had the highest representation of women, while the local government method had the lowest. All three methods had similar representation of scheduled caste/scheduled tribe members.

- Performance, in terms of committees conducting programs, was the highest among committees formed through the local government method (100\%) and the lowest among committees created through the health worker method (78\%). Results for the council meeting method fell in between (94\%).

In the village council method, people knew who had been selected and the reasons why they had been chosen. There were no serious disagreements about members' selection, except in three instances. In one case, the leader finally accepted the people's choice. In another instance, people agreed to include two of the leader's men in the committee. 
However, in the third case, the leader appointed all members of his choice by not allowing anyone to speak in the village meeting. That committee never met again.

There were no major disagreements or complaints about how members were selected using the health worker method. In the local government method, however, there were many complaints because most leaders had not consulted anyone during the process of nominating members. Therefore, people asked the researchers why certain individuals had been selected. They also complained that some clusters had been left out and some had been overrepresented.

Overall, the village council method fared well in ensuring transparency and giving representation to women and the poor. It was also the most time-consuming method, requiring a lot of community facilitators' time and involvement. The health staff was not able to manage council meetings on their own without the community facilitators' presence. They told researchers: "Because community facilitators are outsiders they are respected. We do not get the same response from the village council. So this method is not feasible in our set-up."

Researchers were interested in finding a method that could be used within the government structure and not be dependent on outsiders like the community facilitators. They decided to try a combination method in the remaining seven primary health centres. The combination method included some features of the village council and health worker methods. Health workers listed candidates as before, but instead of consulting a few leaders individually, they called a meeting of government leaders, members of self-help groups, youth groups, caste leaders, community nutrition workers, and teachers to finalize the list. They formed 28 committees in three months, without involving the facilitators. However, the facilitators attended all initial meetings of these committees to find out whether the selection process was proper and if membership norms were being met.

At the end of the project, researchers evaluated the 64 health committees formed using these four methods. They applied eight performance indicators that represented all important aspects of committee functioning like inclusion of women and disadvantaged population groups, transparency, democratic style of functioning, sharing of responsibility, and community involvement (see Table 2). Because all of these aspects were considered equally important, they were given the same weight in the final performance score. This analysis once again showed that the village council method was the best. It scored better than the combination method on all indicators except two. It performed especially well in giving due representation to women. This was the case because community facilitators played a decisive role during the village council meetings and ensured that women participated in these meetings. 
Table 2: Committee performance by method of formation

\begin{tabular}{|l|c|c|c|c|c|}
\hline \multirow{2}{*}{ Indicators } & \multicolumn{5}{|c|}{ Method of Committee Formation (Percent) } \\
\cline { 2 - 6 } & $\begin{array}{c}\text { Village } \\
\text { council } \\
\mathbf{N = 1 6}\end{array}$ & $\begin{array}{c}\text { Health } \\
\text { worker } \\
\mathbf{N = 9}\end{array}$ & $\begin{array}{c}\text { Government } \\
\text { leader } \\
\mathbf{N = 1 1}\end{array}$ & $\begin{array}{c}\text { Combination } \\
\text { method } \\
\mathbf{N = 2 8}\end{array}$ & $\begin{array}{c}\text { Total } \\
\mathbf{N = 6 4}\end{array}$ \\
\hline $\begin{array}{l}\text { Committees had 50 percent or more } \\
\text { female members }\end{array}$ & 75 & 56 & 27 & 43 & 50 \\
\hline $\begin{array}{l}\text { Committees had 40 percent or more } \\
\text { SC/ST members }\end{array}$ & 56 & 33 & 64 & 50 & 52 \\
\hline Committees held meetings & 58 & 45 & 53 & 54 & 54 \\
\hline Members attended committee meetings & 44 & 38 & 34 & 48 & 43 \\
\hline $\begin{array}{l}\text { Committees conducted at least one } \\
\text { program }\end{array}$ & 94 & 78 & 100 & 86 & 89 \\
\hline Committees mobilized resources & 88 & 56 & 63 & 79 & 75 \\
\hline $\begin{array}{l}\text { Committees where members shared } \\
\text { tasks }\end{array}$ & 69 & 30 & 64 & 71 & 64 \\
\hline $\begin{array}{l}\text { Committees had good relationship with } \\
\text { health staff }\end{array}$ & 82 & 78 & 36 & 75 & 70 \\
\hline Total Score & 566 & 414 & 441 & 506 & 497 \\
\hline Average Performance Score & $\mathbf{7 1}$ & $\mathbf{5 2}$ & $\mathbf{5 5}$ & $\mathbf{6 3}$ & $\mathbf{6 2}$ \\
\hline
\end{tabular}

\section{Orienting Committee Members}

After committees were formed, community facilitators organized orientation meetings for their members to discuss:

- Roles and responsibilities

- The Community Needs Assessment Approach (CNNA) under the reproductive and child health program

- Problems clients usually face in getting services at primary health centres

- Actions the health committees were expected to take and not take

The primary health centre staff usually attended these meetings. Typically, the meetings began with community facilitators explaining the purpose of the project and the role health committees were expected to play. The facilitators emphasized the need for members to collaborate and cooperate with health staff, local community based organizations, and the local government.

Health workers then informed committee members about the CNAA under the reproductive and child health program and presented health data collected from their villages. Most members were satisfied with their data, but some expressed doubts about its quality.

Committee members then discussed the problems that people faced in getting services at the primary health care centres. They usually complained about such things as health staff being unfriendly, doctors not giving free medicines, and health staff demanding money or 
not being available. While the health staff were upset by these complaints, most responded politely to members' accusations. Community facilitators repeatedly explained to members that their role was not to find fault with health staff but to work with them. Through such discussions, they ensured that most orientation meetings ended cordially, even though many began belligerently.

At the end of the orientation meeting, researchers asked each committee to choose its first activity. Because researchers felt that the key to stimulating committee members' interest was to ensure that their first activity was a success, they urged them to select activities that were easy to implement and then provided support, if needed. For example, one committee planned a village-level clinic as their first activity. The activity was scheduled to be cancelled because the health worker was on leave that day. The community facilitator then met with the health centre doctor and requested him to send another worker in her place. The doctor agreed and the clinic was held as planned. Facilitators created a calendar of activities that committees in their area had planned, then followed up to find out if they had been implemented, or if the committees needed help.

\section{Provision of Project Inputs}

To help the committees function, the project provided five types of inputs:

1. Community facilitators

2. A start-up grant of Rs. 2000 per committee

3. Identity cards for committee members

4. Organization of bi-annual meetings of committee presidents

5. Publication of a monthly newsletter

Community facilitators were young men and women with college education who were experienced with grassroots level development work. Of the seven facilitators appointed, five came from Mysore District and two originated from North Karnataka. They all had good communication skills, were good listeners, were respectful of the community, and were highly motivated to work as facilitators.

The facilitators attended all of the committee meetings and activities organized in their respective areas. Initially, they gave committee members ideas for activities and helped them identify local resources such as health NGOs and the State Resource Centre to help improve the quality of those activities. They also helped committees keep accounts of funds collected and expenses incurred.

A start-up grant of Rs. 2000 was provided to each committee to meet its expenses. This amount was disbursed in installments, according to their activity levels. The transfer was completed publicly during committee meetings so that all members knew about it. Members collectively decided where to keep the funds and how to spend them. Some committees opened accounts at the post office; some divided the amount among themselves and paid interest on it to the committee.

Community Involvement in Reproductive Health: Findings from Research in Karnataka, India 
Committees spent the funds to organize health activities in their villages. They rarely spent any amount on themselves, not even for reimbursement of their travel expenses. They maintained accounts of receipts and expenses and reported those to community facilitators every month. Reports show that over 90 percent of the committees spent their grants judiciously, and more than half of them had built on the seed money through contributions from members and others.

Committee members received identity cards to legitimise their role and to boost their status in the community. District health officers supported this idea as a way of showing appreciation for their voluntary work, but primary health centre doctors initially opposed it, fearing that members would misuse the card by demanding special privileges.

Facilitators issued the cards and told committee members that the identity cards did not give them any privileges and would be withdrawn if health staff complained about their misuse. No health staff member complained, and members reported many positive experiences because of the card.

Presidents' meetings at the block level gave health workers the opportunity to share their experiences with each other as well as with district and state health officers. During these meetings, community facilitators worked to ensure that all committee presidents felt important and respected. Everyone sat around a large table behind nameplates and had five to seven minutes to address the gathering. Health officers listened to them and promised to cooperate. These meetings succeeded in increasing attendance and stimulating presidents' interest in the project. In the second year of the effort, after all of the committees had become operational, facilitators organized two meetings every six months. The main purpose of the meetings was to give visibility to the committees' activities. There was also discussion of important issues like starting a monthly newsletter and establishing committees focused on adolescent health awareness and RTI diagnosis and treatment. The latter was of particular concern to the government.

A monthly newsletter entitled Arogya Midita informed village health committees about the programs being organized and highlight some innovative ones by using photographs. It also included other items such as a primary health centre doctor's speech given on World Population Day, nutritious recipes by a community nutrition worker, and findings from studies on various topics such as adolescent behaviour and hysterectomy. The newsletter became a prime tool for motivating committees to do more and better programs. For example, when the newsletter reported about an eye camp, one committee organized and five others followed suit by forming their own eye camps. That trend continues to this day. 


\section{Performance of the Health Committees}

This section presents data on how well health committees performed at the end of the project, under each of the three roles expected of them. These roles were:

1. Creating awareness and demand for health services

2. Participating in community's health needs assessment and health planning

3. Fostering trust and understanding between community and health staff

\section{Creating Health Awareness}

Most health committees first focused on creating health awareness in their communities by organizing awareness or service programs. In one year, 57 out of 64 committees ( 89 percent) organized 172 programs of 18 different types while seven committees (11 percent) had organized none. On average, each committee organized three programs per year (see Table 3).

Committees typically planned these programs in consultation with health staff. The community facilitators generally encouraged them to undertake programs focused on reproductive and child health such as adolescent health, family life education for newlyweds, and treatment of RTIs/STIs. They also helped incorporate participatory methods like games, songs, skits, and quizzes in the programs. Committee members followed some traditional practices like personally inviting pregnant women by going to their homes and honouring them by giving them fruits, coconuts, or token gifts. This combination of participatory methods and traditional practices made their programs very attractive. As one young mother reported, "I was reluctant to come for this program, but I am glad I came. They honoured me and made me feel good."

All programs were well attended, with 50 to 350 people per program. Many of the activities were reported in local newspapers. The most popular was the adolescent program, followed by one to promote awareness of antenatal care and nutrition for mothers. Over 60 percent of the committees organized an adolescent program. In the first year of the project, diagnostic and treatment camps were limited, but as committees gained experience and confidence, they began organizing more with the help of local service NGOs. 
Table 3: List of programs carried out by committees as of June 2002

\begin{tabular}{|l|c|c|}
\hline Name of program & $\begin{array}{c}\text { Number } \\
\text { by type of } \\
\text { program }\end{array}$ & $\begin{array}{c}\text { Percent of } \\
\text { Committees } \\
\text { carried out } \\
\text { programs }\end{array}$ \\
\hline Awareness program for adolescent boys and girls & 35 & 62 \\
\hline Awareness program on ANC care & 32 & 56 \\
\hline Awareness program on nutrition for mothers & 28 & 50 \\
\hline Awareness program on diarrhoea control and ORS & 13 & 22 \\
\hline Village cleanliness drive involving school children & 13 & 22 \\
\hline Health awareness program for newlywed couples & 11 & 19 \\
\hline Awareness program on government health services & 9 & 16 \\
\hline First aid training for committee members & 5 & 9 \\
\hline Free eye check-up camp* & 5 & 22 \\
\hline Awareness program on RTI/STI & 4 & 7 \\
\hline Getting water tank cleaned in the village & 4 & 7 \\
\hline Awareness program on gender sensitisation** & 3 & 5 \\
\hline Anti-malaria drive & 3 & 5 \\
\hline Awareness program on prevention, control and treatment of & 2 & 3 \\
acute respiratory infection & 2 & 3 \\
\hline Free health check-up & 2 & 3 \\
\hline Celebrated World Health Day/lnternational Women's Day & 2 & 2 \\
\hline Training committee members to weigh newborns & 1 & 5 \\
\hline RTI/STI detection and treatment camp* & 1 & $\mathbf{8 9}$ \\
\hline Total programs & $\mathbf{1 7 3}$ & \\
\hline
\end{tabular}

${ }^{*}$ Two to three committees usually jointly organized diagnostic and treatment camps.

** Even though there were only three programs specifically on gender sensitisation, gender issues have been addressed in all programs on nutrition, pregnancy, adolescents and newlywed couples.

\section{Assessing Communities' Health Needs}

After organizing health awareness activities for eight months, committee members had learned about various components of the reproductive and child health program, however they were not clear about their role in the CNAA. Some members periodically accompanied health workers while they carried out the CNAA survey, but they were not involved in developing workers' plans. Some of them used CNAA data to choose which activities to undertake. For example, one committee planned a maternal health care awareness program because CNAA data showed a low level of institutional deliveries.

Since involvement in the CNAA plan was one of the roles envisioned for committees, researchers tried to find out from both health workers and committee members how they could help each other. Health workers were willing to let members accompany them during household surveys, but they did not think that their involvement would help improve the survey's quality. Instead, they requested printed registers, which the researchers provided. Health workers were pleased with this cooperation and shared their data with committee members and community facilitators. 
Committee members' ideas about the needs assessment varied greatly from those proposed under the CNAA approach. Committees wanted to focus on meeting the health needs of the extremely poor in their community, and some of them considered giving money to this group during health emergencies. They quickly realized, however, that they did not have sufficient resources to do this. "If we start giving money, everybody would claim to be poor. Then we would be inviting trouble," one committee member said. One committee wanted primary health centre doctors to give free medicine to the poor. The doctors rejected that idea saying, "The government had no such scheme."

Some committees proposed helping the poor get benefits from various government welfare programs such as the old age pension and rehabilitation for disabled persons. Based on that idea, they started a "pro-poor planning" exercise in addition to the CNAA plan. This exercise consisted of four steps:

1. Identify the poor

2. Develop a household register of the poor members of the community

3. Identify the problems of the poor

4. List actions to address those problems

Using the CNAA register, committee members identified the poor families in their villages. They defined "poor" as those individuals earning their livelihood only through daily wages, or those having difficulty obtaining two meals a day. Sometimes they used their judgment to decide whether a family was poor. For example, a family in which the sole wage-earning member had gangrene was included on the list even though that family did not meet any of the other criteria of being poor.

After identifying the poor households, committee members visited them to find out about their health problems and their access to health and welfare services (see Appendix 1 for a list of the questions that were asked). Community facilitators and some primary doctors helped them to compile that data, identify priority problems of the poor, and decide what actions they could take to address those problems (see Appendix 2 for details).

One committee, for example, found many malnourished children among the poor. Because the village had no community nutrition workers, they decided to monitor the children's growth with the help of workers from the neighbouring village. Another committee found many disabled children among the poor so they planned an "awareness with service" camp for them through the District Rehabilitation Centre. At the time of this evaluation, five committees had undertaken such special plans.

\section{Building Trust and Commitment with Health Providers}

From the beginning of the project, committee members viewed health staff as partners in the project and sought their involvement. As a result, most committees involved health staff as resource persons in their programs. Local newspapers published the names and photos of health staff when they attended committees' programs. They gave program 
ideas to committee members and helped contact other resources. One worker suggested to her committee that they organize an eye camp because there were more than 40 cataract cases in their area. She also suggested contacting the eye specialist at the Taluk hospital. The committee acted on her suggestion and organized an impressive camp, which became a model for other committees to follow. In another instance, a primary health centre doctor put the committee in touch with the Vedavati Charitable Trust, which was recognized by the District Blindness Control Society for organizing eye camps. As a result of these efforts, the interaction between the health staff and committee members increased and brought about positive changes in the health staff's attitude toward them. Out of 64 committees, one-third (22) developed very good relationships with health staff while another third (23) developed moderately good relationships. Community facilitators made this assessment based on field observations about how regularly health workers attended committee meetings, whether or not they participated in committees' programs, and whether they showed each other respect. During the baseline survey, only 20 percent of the health staff supported the idea of establishing committees. At the time of the final evaluation, however, nearly 80 percent of health workers gave positive feedback about health committees. One health worker reported, "If we are friendly with committee members, they ease our burden in the field."

\section{THE IMPACT OF THE COMMITTEE}

After completing the two-year project period in June 2002, researchers evaluated the impact of the project in terms of community involvement and utilization of reproductive and child health services. They used process and outcome indicators (see Box 1 below). Process indicators assessed the level of community involvement for people's participation in committee programs and committees' ability to mobilize local resources and involve other community-based organisations (including local governments) in health activities. Outcome indicators measured changes in the awareness and utilization of reproductive and child health services. Data for evaluation came from a household survey similar to the baseline survey and from interviews with health staff, committee members, and local leaders. 


\section{Box 1: List of process and outcome indicators}

\section{Process Indicators}

Percent of committees that conducted health activities

Percent of committees that mobilized local resources for their activities

Percent of committees with self-motivation and networking capacity

Percent of committees that practiced cohesive and collective style of functioning

Percent of committees with respectful and supportive relationships with health staff

\section{Outcome Indicators}

Percent of pregnant women who received full prenatal care and safe delivery

Percent of contraceptive users who reported to be self-motivated and

suffered no side effects

Percent of women who knew about RTI/STIs and sought treatment when

there were problems

Percent of women who followed appropriate child care practices

Percent women who participated in health committees' activities

\section{Performance on Process Indicators}

\section{Community involvement in health activities}

Out of 64 committees, 57 were active at the time of the evaluation, three had stopped functioning, and four had never become active. Two stopped functioning because health staff and committee presidents had quarrelled. The third dissolved because the president stopped taking interest in committee activities but continued to control the funds. The four committees that never became active had problems both with workers and members. Health workers did not participate in committee meetings because they were busy holding additional charges for other sub-centres. Unfortunately, members of these committees were not very enthusiastic. One of these committees, however, became very active after the study was completed because community facilitators were so persistent.

The 57 active committees carried out 172 programs over a period of 10 months, averaging one program per quarter. There were 17 very active committees among them, which conducted health programs every other month. The remaining 40 committees were moderately active and organized programs every four to five months (see Table 4).

"Moderately active" committees typically organized large programs that attracted many participants and then began smaller programs after much time had lapsed. The very active committees, on the other hand, organized more frequent programs of manageable size.

"Very active" committees were usually the first to begin new types of activities. One of them, for example, organized an RTI/STI detection camp for the first time by inviting a local NGO, the Vivekananda Youth Movement. Another committee put together an adolescent program that involved health staff. A third committee organized an eye camp. 
All of these activities became models for other committees to follow. They were all well attended because committees ensured that these occasions were interesting and festive.

Table 4: Activity level of committees by programs, attendance and expenditure

\begin{tabular}{|l|c|c|c|}
\hline $\begin{array}{l}\text { Activity level of } \\
\text { committees }\end{array}$ & $\begin{array}{c}\text { Average number } \\
\text { of programs per } \\
\text { committee }\end{array}$ & $\begin{array}{c}\text { Average } \\
\text { attendance } \\
\text { at programs }\end{array}$ & $\begin{array}{c}\text { Average amount } \\
\text { spent per } \\
\text { program (Rs.) }\end{array}$ \\
\hline Very Active (17) & 4.9 & 50 & 404 \\
\hline Moderately Active (40) & 2.2 & 45 & 402 \\
\hline Total Active (57) & $\mathbf{3 . 0}$ & $\mathbf{4 7}$ & $\mathbf{4 0 3}$ \\
\hline
\end{tabular}

Over 42 percent of households reported that they knew about or participated in health committee groups (see Table 5). Participation was consistent across caste and education groups but was much lower among the poor households $(29 \%)$ as compared with the nonpoor households $(50 \%)$. This was an unfortunate, but not unexpected, finding. The poor, who needed the community approach most, benefited from it the least because they could not afford the time for it. Interestingly, many committee members were aware that the very poor in their community were not participating in their programs. This group, which constituted about 10 percent of total households, was not the same group that the government had identified as falling below the poverty line. The poor, as identified by the project, lived in thatched huts and depended solely on unskilled, low-paying work for their livelihood. Community members identified them as being "very poor." This experiment showed that even a high level of community participation does not ensure adequate participation by the poor; they need special attention.

Table 5: Participation and knowledge about the committee by household characteristics

\begin{tabular}{|l|c|c|}
\hline Characteristics & $\begin{array}{c}\text { Number of } \\
\text { households }\end{array}$ & $\begin{array}{c}\text { Percent who knew of or } \\
\text { had participated in } \\
\text { committee activities }\end{array}$ \\
\hline $\begin{array}{l}\text { Illiterate or functionally literate } \\
\text { women }\end{array}$ & 690 & 48 \\
\hline $\begin{array}{l}\text { Educated women (more than four } \\
\text { years) }\end{array}$ & 302 & 58 \\
\hline Scheduled castes/scheduled tribes & 522 & 46 \\
\hline Other castes & 512 & 52 \\
\hline Poor households & 62 & 29 \\
\hline Modestly poor households & 988 & 50 \\
\hline Total & $\mathbf{1 , 0 5 5}$ & $\mathbf{4 2}$ \\
\hline
\end{tabular}

Missing data: Education level not known (58), Caste not known (16)

Community Involvement in Reproductive Health:

Findings from Research in Karnataka, India 


\section{Mobilizing resources}

FRHS provided an initial grant of Rs. 2000 to each committee to get them started, but committees also generated additional resources from local philanthropists, village councils, self-help groups, and religious establishments. Donations were almost always in-kind or service, to avoid cash transactions (see Box 2 for one example). Out of 57 active committees, 25 generated over 60 percent of their expenditure locally, 20 generated less than 40 percent, and 12 generated none. At the time of the evaluation, committees had spent only about Rs. 21,000 out of the initial grant of Rs. 92,500 that they received, had mobilized over Rs. 48,000 in kind, and had saved about Rs. 71,500 for their future activities.

\section{Box 2: Illustrations of committees mobilizing resources}

When KM Halli village committee decided to organize an adolescent awareness program in a local school, they invited teachers and the headmaster to their monthly meeting. The headmaster and teachers agreed to allot one whole day for the program. Based on the community facilitator's suggestion, the committee president called the State Resource Centre (SRC) in Mysore and confirmed its availability. Committee members then asked a local religious establishment to make food arrangements. They obtained a microphone system free of charge and hired a hall for a nominal fee because this was a social cause. "We prefer to take help in-kind because then everyone can see how we are using their contribution and there is no room for suspicion," said the president.

While there were no misappropriations of funds, there were three instances where presidents kept some of the grant money and promised to return it later. Until it was repaid, the money was unavailable for committees' activities. One of the committees stopped functioning, but the other two continued their activities because members were confident that one day they would secure the borrowed funds.

\section{Self-motivation and local networking}

Another indicator used to assess committee performance was the extent to which committees demonstrated motivation in organizing health activities. Twenty-five committees (39\%) did very well; their community facilitators did not have to remind them to conduct programs. Their motivation came from people in the community who encouraged them to organize programs. Another 32 committees $(50 \%)$ needed some prodding from facilitators. They expected the facilitators to remind them of their duties, to give them ideas on what to do, and to provide support. In the remaining seven committees $(11 \%)$, the facilitator was not able to activate them.

More than half of the active committees also showed the capacity to network with other community-based organizations, NGOs, and local governments. Some of these committees organized programs jointly to reduce costs and obtain more resources. They invited other NGOs to help them carry out activities (see Box 3). Nearly all of the 
committees had the active involvement of self-help groups, continuing education centres, youth groups, and local governments.

\section{Box 3: An illustration of networking capacity}

The Ratnapuri village committee was very enthusiastic. They conducted an ANC program within a few weeks of their formation. Their second activity was an eye camp. The committee president asked a PHC Medical Officer to suggest whom to invite. The medical officer put him in touch with a trust he knew in Mysore, which had been approved by the District Blindness Control Society.

After finalizing the date, the president convened a meeting of PHC staff, presidents of other health committees, self-help group facilitators, local government presidents, staff from a local NGO, bankers association, transport owners' association, and facilitators of Continuing Education Centers (CEC) to discuss arrangements and funds for the camp. Each group agreed to assume a particular responsibility.

On the day of the camp, the CEC facilitators served as coordinators. Self-help groups made lists of persons with eye problems and brought them to the camp. Local presidents supplied food. The transport owners' association made arrangements to transport 32 cataract patients to Mysore and back, free of charge. NGOs made arrangements for publicity and the bankers association contributed money. About 300 eye exams were conducted during the camp.

Almost all of the committees enjoyed good relationships with village committee leaders. The leaders were involved in forming the committees, regularly participated in meetings and contributed funds for some of the activities. Only in five cases did community leaders create trouble for the committees. In one case, one faction of the local government supported the committee while the other opposed it. In the other four cases, committee presidents were also community leaders and had no time for the committee work.

Most other committees managed to strike a balance between involving community leaders and allowing them to control the committee. Many leaders thought committees made meaningful efforts to improve people's health. As one said, "We have learnt a lot from our health committees. This is the only time we have been meaningfully involved in improving [the] health of our community." Some community leaders had transferred funds for chlorinating village water supplies to committees to carry out that work.

\section{COMMITTEES' STYLE OF FUNCTIONING}

To assess whether committees functioned in democratic style, researchers used three indicators: 1) regularity of meetings, 2) attendance at meetings, and 3) sharing tasks among members. On all three indicators, the committees were average. Overall, they held 54 percent of scheduled monthly meetings. An average of 43 percent of members attended meetings. In 61 percent of the committees, members shared tasks amongst themselves, while in the remaining committees only one or two members were active. 
Regular attendance at monthly meetings was difficult for many members because they came from different villages and belonged to different socioeconomic classes. Those from higher income families could afford to attend meetings regularly while those from poorer families could not. Some committees discussed constraints on poor members' participation and even considered paying them for their time. They finally decided against it saying, "If we pay them, then everybody will claim to be poor. If [the] poor want to participate, they must find time for it."

"Very active" committees met more regularly than "moderately active" committees did. Both sets of committees performed similarly on the other two indicators (see Figure 1).

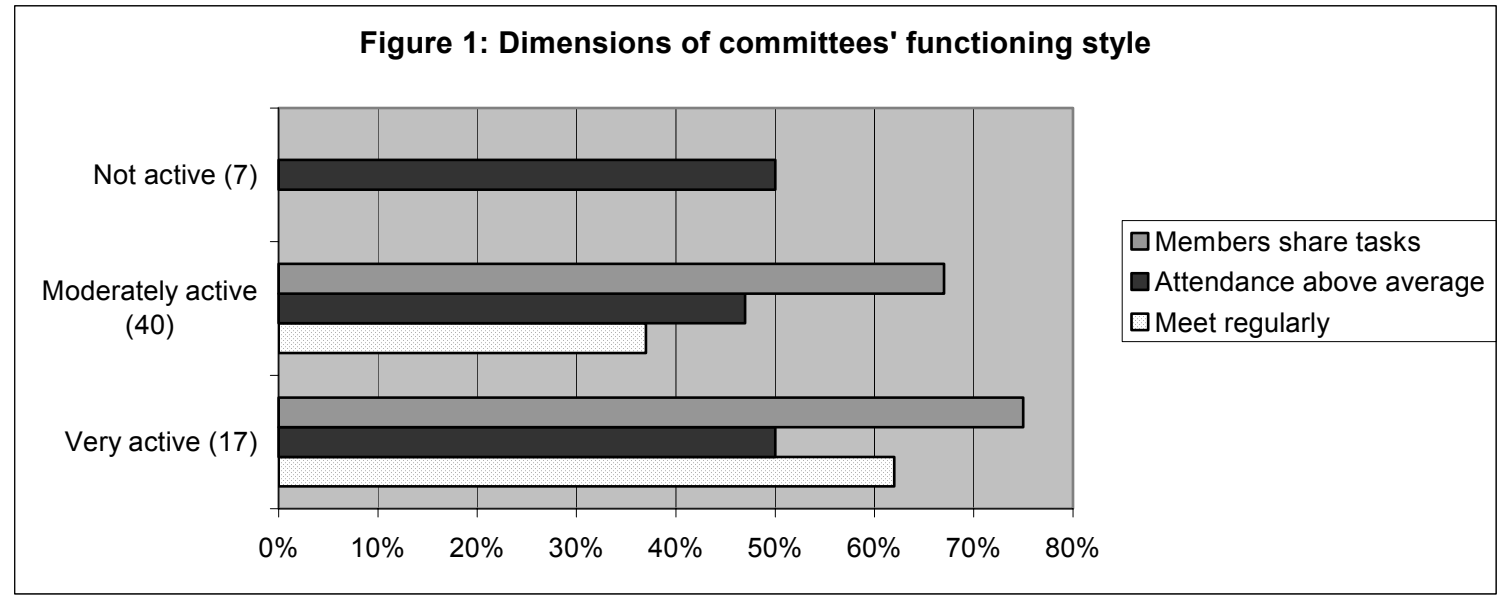

Committees' functioning styles varied, but this did not seem to be related to their activity level. In some committees, presidents made all of the decisions and others followed. In others, members made decisions collectively but left actions to one or two members. A few committees always worked jointly so that they could organize large-scale activities. Other committees fought bitterly during meetings but then organized excellent programs.

\section{Relations with health staff}

In this project, researchers paid special attention to ensure that health committees developed collaborative relationships with health staff. This task initially seemed difficult because at the start of the project most health staff opposed the idea of establishing committees. Only 20 percent of them held positive views, 38 percent were neutral, and 42 percent had negative opinions about the project. Health staff feared that committee members would try to control them or to interfere in their work.

Despite their apprehensions, 55 committees (70\%) managed to develop average to very good relationships with health staff; only 30 percent of committees reported poor relationships. Most of the very active committees experienced good relationships, most of the non-active ones experienced poor relationships, and among the moderately active committees the picture was more mixed. The credit for maintaining good relationships 
went equally to health staff and committee members. Committees with good relationships usually worked with health staff that had positive or neutral attitudes to begin with. Health staff gave committee members ideas and helped them conduct programs. Committee members, in turn, showed concerns for workers' personal safety, heavy workload, and family problems. Committees with average relationships typically had staffs that were not interested in getting involved in committee activities either because they were too busy or unmotivated. Committee members did not always insist that the health staff get involved. Both adopted a "live and let live" policy.

In some cases, however, where health staff held negative views and committees insisted that they get involved, relationships turned sour. In two such instances, committee presidents complained about health staff to district officers. In some cases, health staff tried to disrupt committee activities by discouraging members from participating.

\section{Performance on Outcome Indicators}

In terms of improvement in awareness and access to reproductive and child health services, the household survey showed significant gains over the baseline survey on some indicators but not on others (see Table 6). Indicators that showed gains were institutional deliveries (from 32 to $39 \%$ ), women seeking treatment for RTI/STI (from 32 to 56\%), and weighing babies at birth (from 21 to $43 \%$ ).

Table 6: Status of outcome on reproductive and child health indicators

\begin{tabular}{|l|c|c|c|c|}
\hline & \multicolumn{2}{|c|}{$\begin{array}{c}\text { Experimental Block } \\
\text { (Percentage) }\end{array}$} & \multicolumn{2}{c|}{$\begin{array}{c}\text { Control Block } \\
\text { (Percentage) }\end{array}$} \\
\hline & $\begin{array}{c}\text { Baseline } \\
\mathbf{N = 1 , 0 5 7}\end{array}$ & $\begin{array}{c}\text { Final } \\
\mathbf{N = 1 , 0 5 0}\end{array}$ & $\begin{array}{c}\text { Baseline } \\
\mathbf{N = 1 , 0 4 8}\end{array}$ & $\begin{array}{c}\text { Final } \\
\mathbf{N = 1 , 0 5 2}\end{array}$ \\
\hline $\begin{array}{l}\text { 1. Couples using family planning } \\
\text { method }\end{array}$ & 72 & 75 & 67 & $73^{*}$ \\
\hline $\begin{array}{l}\text { 2. Reported no contraceptive side } \\
\text { effects }\end{array}$ & 66 & $76^{*}$ & 83 & $87^{*}$ \\
\hline 3. Pregnant sought antenatal care & 95 & 97 & 98 & 99 \\
\hline 4. Received 3 ANC visits + TT + IFA & 74 & $67^{*}$ & 84 & 83 \\
\hline 5. Received more than 90 IFA tablets & 30 & $37^{*}$ & 64 & $48^{*}$ \\
\hline 6. Institutional deliveries & 32 & $39^{*}$ & 50 & $57^{*}$ \\
\hline $\begin{array}{l}\text { 7. Deliveries attended by health } \\
\text { professionals }\end{array}$ & 40 & $49^{*}$ & 56 & $61^{*}$ \\
\hline 8. Reported immediate breastfeeding & 32 & 34 & 15 & $32^{*}$ \\
\hline 9. Babies weighed at birth & 21 & $43^{*}$ & 34 & $50^{*}$ \\
\hline $\begin{array}{l}\text { 10. Mothers knew about giving ORS } \\
\text { to children with diarrhea }\end{array}$ & 47 & $23^{*}$ & 19 & $13^{*}$ \\
\hline 11. Children fully immunized & 96 & $92^{*}$ & 97 & 96 \\
\hline 12. Sought treatment for RTI & 32 & $56^{*}$ & 28 & $56^{*}$ \\
\hline $\begin{array}{l}\text { 13. Women had heard about } \\
\text { HIV/AIDS }\end{array}$ & 62 & 66 & 69 & $73^{*}$ \\
\hline
\end{tabular}

${ }^{*} p<.05$ for comparison between baseline and endline in each column 
Contraceptive use increased modestly from 72 to 75 percent and there was a significant increase in family planning acceptors who reported no side effects (from 66 to $76 \%$ ). This result may indicate that women had received the contraceptive method of their choice and had made that own decision about adopting the method. There was a sizable increase in women in the experimental block (from 60 to $78 \%$, not shown in the table) that reported deciding to use contraceptives on their own. This result may indicate women's increased sense of empowerment.

The survey also registered a significant decline in the proportion of women who said that they would give ORS if their child had diarrhea (from 47 to $23 \%$ ). Furthermore, it showed that there was a significant increase in the proportion of women who said that they would take the child to a doctor or hospital (from 27 to 59\%, not shown in Table 6). These findings surprised researchers because over one-fifth of the committees had organized ORS programs and invited health staff as resource persons. These programs always included demonstrations by women about how to make ORS, a competition for school children, and further lecture demonstrations by resource persons. These lectures usually ended with the message, "ORS is a primary level of treatment, and if diarrhea persists take the child to doctor." It appears that women registered the latter part of the message better than the first part about the importance of giving ORS.

In the control block, as mentioned earlier, there was already a health $\mathrm{NGO}$ working in the area to provide health care and conduct a project to promote community participation using rapid rural appraisal methodology. As a result, from the start, health indicators in this block were better than those in the experimental block. At the end of the project, the experimental block recorded more progress on the majority of indicators, substantially reducing the gap between the two blocks.

The impact evaluation showed that this health committee model was effective in evoking community participation. This was confirmed by the process indicators and by the finding that 42 percent of households had reported knowing of or having participated in health committees' activities. It showed an impact on the quality of family planning services as women reported fewer contraceptive side effects (see indicator 2 in Table 7).

Community Involvement in Reproductive Health:

Findings from Research in Karnataka, India 


\section{Table 7: Percent changes in the "before" and "after" measures of outcome indicators}

\begin{tabular}{|l|c|c|}
\hline Indicators & $\begin{array}{c}\text { Experimental } \\
\text { Block } \\
\text { (Percent } \\
\text { Change) }\end{array}$ & $\begin{array}{c}\text { Control } \\
\text { Block } \\
\text { (Percent } \\
\text { Change) }\end{array}$ \\
\hline 1. Couples using family planning method & 4 & $9^{*}$ \\
\hline 2. Reported no contraceptive side effects & $15^{*}$ & $5^{*}$ \\
\hline 3. Pregnant sought antenatal care & 2 & 1 \\
\hline 4. Received 3 ANC visits + TT + IFA & $-10^{*}$ & -1 \\
\hline 5. Received more than 90 IFA tablets & $23^{*}$ & $-25^{*}$ \\
\hline 6. Institutional deliveries & $21^{*}$ & $14^{*}$ \\
\hline $\begin{array}{l}\text { 7. Deliveries attended by health } \\
\text { professionals }\end{array}$ & $22^{*}$ & $9^{*}$ \\
\hline 8. Reported immediate breastfeeding & 6 & $114^{*}$ \\
\hline 9. Babies weighed at birth & $103^{*}$ & $48^{*}$ \\
\hline $\begin{array}{l}\text { 10. Mothers knew about giving ORS to } \\
\text { children with diarrhea }\end{array}$ & $-51^{*}$ & $-31^{*}$ \\
\hline 11. Children fully immunized & $-4^{*}$ & -1 \\
\hline 12. Sought treatment for RTI & $75^{*}$ & $100^{*}$ \\
\hline 13. Women had heard about HIVIAIDS & 6 & $6^{*}$ \\
\hline
\end{tabular}

${ }^{*} p<.05$ for comparison between baseline and endline

** Health professionals include doctor, nurses, lady health supervisors and auxiliary nurse midwife but exclude trained traditional birth attendants (TBA).

However the experimental block showed a slight decline in the third ANC visit between the baseline and the final surveys. There was no change in women receiving two tetanus toxiod injections, while the percent of women getting more than 90 iron-folic acid tablets, a three month supply, actually increased 23 percent in the experimental block and declined 25 percent in the control block.

\section{FACTORS CONTRIBUTING TO THE EFFECTIVENESS OF THE COMMITTEE MODEL}

Although the idea of forming village health committees was not new, this project tested a new model of health committee. Health committees were not expected to play a dependent role (i.e. government decides what they should do and provides funds) or an adversarial one (i.e. acts as a pressure group). Instead, they assumed a collaborative role of working in partnership with health staff and community-based organizations. Thus, the success of this model depended on how well committees managed to play that role and resist pressures to either become dependent on the government or act more like an advocacy organization.

Most health committees established earlier had members who were village-level functionaries like school teachers, nutrition teachers, community leaders, or other persons with high status and influence in the community. They were expected to attend 
committee meetings that workers organized periodically and to help with activities like the Pulse Polio Campaign or recruiting family planning cases.

In the committee model tested in this project, members came from different localities in their respective villages. They were selected by community members and were expected to organize activities to improve awareness and access to health services. However, they had no financial or administrative power over the health staff, except for the start-up grant that they had received. They were expected to raise resources for their activities and to carry out their tasks in collaboration with health staff and community leaders, all of whom had different expectations of them.

Health staff wanted health committees to passively participate in activities that they had selected. They doubted the committees' abilities to identify health problems and to organize programs. They were also worried that committees would want to supervise their work and harass them. The initial orientation meetings for the health committees confirmed these fears. Members would ask questions like, "Why do doctors take money?" "Why do they always give prescriptions?" "Who gets free medicine that the government buys?" "Why does health staff come late?" At that point, many doctors and health workers wanted to opt out of the experiment. The District Health Officer persuaded them to continue, noting, "Community participation is a government policy." Community leaders, on the other hand, wanted health committees to function as watchdogs of the health system. They wanted them to report whether health workers visited villages, which doctors took money, or whether PHC staff were keeping accurate records of staff time.

The committees seemed to serve as a bridge between community and health staff to help create greater awareness about health in the community. Most of the committees played the bridging role successfully, resisting pressure to fall in line with health workers' or community leaders' expectations. The next section describes what factors helped committees play that role.

\section{Credibility of the Committees}

First, building the committees' credibility was an important factor in helping them play the bridging role. Since the government had not formed these committees, the government health staff was not sure that they needed to cooperate with them. Community leaders also wondered why these new committees had been formed when they could have created health committees under the existing system.

Committee members were not sure about the legitimacy of their role. Some committee members requested identification cards to legitimise their role. The cards helped, but credibility really increased as the committees began organizing programs. Health staff were invited to the activities, and news about the programs began to appear in local newspapers. After reading about the committees' activities, other NGOs in the area, like

Community Involvement in Reproductive Health: Findings from Research in Karnataka, India 
the State Resource Centre and the Vivekananda Youth Movement, expressed interest in working with them.

The start-up grant, which was considered small, also helped build credibility for the committees because they could spend money up front for their activities. This helped generate more funds through donations. As one member explained, "Because we had this money we could make our programs more interesting, like having competitions and giving prizes. It helped to attract more people for our programs. After seeing our programs, people are now willing to help."

Meetings of committee presidents also helped build credibility. At these meetings, presidents met with state and district level officers who appreciated their efforts. After attending such a meeting, one president had said, "I thought this was one of those committees that got formed but did nothing. But when I attended this meeting and saw other presidents talk about their work and district officers appreciating them, I realized that this committee was different. That was when I decided to do something."

The process of building the credibility of the committees took eight to ten months. Committees contributed to the process by guarding their reputation in financial matters, and by not aligning themselves with any political interest or seeking political gain from their work. Since members belonged to different political parties, they ensured that no one party took advantage of them. Thus far, only one committee has broken this rule. The committee's president complained about a health worker to the local member of the legislative assembly, who reprimanded her publicly. As a result, the committee lost the goodwill of health staff and has not been able to organize any programs since then.

\section{Organizing Capacity}

Community facilitators contributed a great deal toward building the organizational capacity of the committees. They gave the committees ideas about what programs to organize and how to structure them. They helped to identify other NGOs and resource institutions that could collaborate to make the programs more effective. They advised committee members about getting cooperation from health staff. In the final evaluation, many committee members cited the effectiveness of the community facilitators.

"Community facilitators guided us about programs. They helped us to solve problems among ourselves and improve our relations with doctor."

Newsletters also helped develop committees' organizing capacity by connecting them to other health committees. They learned about each other's experiences and ideas, which they found useful for organizing their programs. As one committee president said, "From the newsletter we came to know about the VC Trust in Mysore for eye camp. We then contacted them [to establish a] program in our village." 


\section{Motivation}

Sustaining committee members' motivation over a two-year period was a major challenge because all members were volunteers and received no money for their time and effort. Public appreciation was their only reward, which they received mainly through the newsletter and newspapers. As one committee's members reported, "The village cleanliness drive that we had organized was reported in the Arogya Midita along with our photographs. We showed it to the people in the village. After that, people started participating in our programs in larger numbers."

The block-level meeting was another opportunity for committee presidents to display their work to a larger audience and to receive appreciation from district and state government officers. This intangible reward strengthened their resolve to do more for their people. One president described how the block-level meeting had helped him, "People used to say if I was not getting anything then why was I running around for health committee? I used to feel bad about it. But when I came for this meeting and saw so many presidents talk about their work, I felt very motivated. Then I felt that I should not care for what others say. I must work to make my committee successful."

The identity card was also a source of motivation. Members wore them during programs and many carried them when they visited health facilities. They found that health providers treated them respectfully, both inside and outside of Hunsur. One reported, "I had taken a relative to Bangalore for treatment at a private hospital. I was wearing the Icard. The doctor asked me about it. He was very impressed by our seva monbhavane (service motivation) and praised us. He also reduced the bill. I feel that social service also brings a lot of recognition."

All of these inputs together sustained community members' motivation. The result was impressive: about 88 percent of committees remained active for about two years and continued working even after the project was over. Two-thirds mobilized local resources and felt confident that they could do more. People, both inside and outside of Hunsur, appreciated their efforts, which added to the committees' motivation and their desire to continue working.

\section{SUSTAINING AND SCALING UP THE COMMITTEE MODEL}

Sustaining the committee model involves maintaining committees' credibility, organizing capacity, and motivation. How to achieve that remains an open question.

In this project, FRHS facilitated health committee activities by linking them with other government and nongovernmental organizations to support various activities. The committee members' incentive was public appreciation that they received through local media, newsletters, and presidents' meetings. They also received support and collaboration from community leaders and health staff. The researchers received 
excellent support from state and district-level offices. They attended all project-related meetings and supported the researchers when primary health care doctors initially wanted to opt out of the project. This level of support is more than adequate to sustain health committees beyond the project period, as a legitimate village level institution.

Health committees cannot work in isolation without the support and participation of the government health department. However, the strength and uniqueness of the model will be lost if the health department expects committees to function like assistants to health workers. The health committees' ability to initiate activities and collaborate with health staff must be sustained to ensure the meaningful involvement of the community. Committees must be helped to retain their independence and work as partners with the health system.

One strategy for doing this would be to link them with mechanisms, like the Rogi Kalyan Samilthi or the Board of Health Visitors, that already exist at block and district levels. Both of these are committees consisting of elected representatives, members of civil society, and officers from health departments. Their roles involve overseeing the functions of district- and block-level hospitals, as well as deciding on policies governing utilization of user fees and improving government health facilities. If village health committees were linked with these committees, they could be integrated into the health system. Block Health Education Officers could play the role of community facilitator, including publishing the newsletter.

For this model to be sustained, local governments must continue to support the new health committees and the village council structure, instead of appointing health standing committees of their own. They must recognize that these committees cannot assume a watchdog role because if they did, they would fail to get cooperation from health staff, which is essential for role in bridging with the community. They also need to retain their apolitical stance, which is a difficult balance to achieve because they are elected bodies. Therefore, this arrangement will require field-testing. If it works, the model could be scaled up with minimal NGO support.

There are, however, two reasons why this model may always require NGO support to function effectively. First, health committees need help to identify and access nongovernmental sources of information and support. An NGO can play that role more effectively than any government or semi-government organization. Secondly, health committees need regular inputs to empower them within the health system if they are to be considered partners and not subservient to the health system. They will continue to require the type of support that FRHS provided in this intervention, although not with the same intensity.

While scaling up this model from block to district level, it will be important to ensure that all of its unique features are retained: 1) broad-based structure; 2) people's involvement in the formation of the project; and 3) clear definition of roles. This experiment showed that the best method for forming committees was through the village committee method because it gave adequate representation to women and the poor. However, the method is 
time-consuming and requires the involvement of outsiders like community facilitators to help further the process. Thus, during the scaling-up phase, it might be necessary to involve local NGOs to play that role. The model should be scaled up gradually by involving active health committee members from older blocks as facilitators.

\section{SUMMARY AND LESSONS LEARNED}

This project tested a new model of health committee to help stimulate community participation in reproductive and child health activities at the village level. The model involved selecting committee members to represent clusters of 50 to 60 houses. Members of the committee were nominated by the community and not by the government. In addition, committee members were volunteers and received no payment for their services. Rather, they sometimes contributed funds for committee activities.

This experiment was conducted in the Hunsur block of the Mysore District in Karnataka for a period of two years. During this time, a total of 64 committees were formed (one per rural sub-centre), 57 of which were active at the time of this evaluation. One year after the project formally ended, 61 committees were still active with minimal involvement of a community facilitator.

It took time for health staff and committee members to understand and accept their respective roles in the new model. The committees' roles, as envisaged in the model, were to promote health activities in partnership with health staff, not by trying to either control or be subservient to them. Although local leaders wanted to use these committees to monitor health staff, they quickly accepted this new role. Health staff had many reservations about the new system. Health supervisors challenged the researchers by saying, "Don't tell me committees have worked in Kerala and Maharashtra. Show me one place where they have worked in Karnataka." Moreover, they were right. The concept of health committees had not worked in the government health program in Karnataka, although it had worked well in the state's primary education program.

Initially, therefore, some health workers and supervisors tried to convince committee members not to participate in the project. They would ask, "Why do you bother? Are they [FRHS] paying you?" Some created hurdles by not cooperating with committees or helping them to carry out activities. As more and more committees began to function, started organizing health awareness and service camps, and gained visibility, most health staff changed their views and eventually became active participants in committee activities. Initially, only 20 percent of health staff had positive views about the committees, 38 percent were neutral, and 42 percent had negative opinions. At the end of the project, 80 percent reported having positive attitudes.

Committees planned health activities based either on local needs assessments conducted by health staff or by taking cues from neighbouring committees. They generated resources and sought support from friendly doctors, health workers, and other community-based organizations to implement their activities. Through such support, they

Community Involvement in Reproductive Health:

Findings from Research in Karnataka, India 
were able to reach over 40 percent of households with their programs, providing health education and services, at practically no cost to, and with little effort from, the health department. Most importantly, most committees functioned without antagonizing local politicians or health workers and without taking political advantage of their work.

An impact evaluation conducted at the end of the project showed that over 85 percent of committees had been active in organizing health programs. Most programs were of good quality and were well attended. About half of the people in the community reported knowing of or participating in the programs. Over two-thirds of health staff provided a high to moderate level of support to these programs. Health staff were particularly pleased with committees that invited and honoured them. Over 90 percent of committees also enjoyed support from local governments and received donations from their funds. Survey data from before and after the experiment recorded significant increases in awareness of, and access to, certain reproductive and child health services such as treatment of RTI/STI, safe delivery, and weighing babies at birth. The control block, where another NGO was active in providing health care, also showed gains on most reproductive and child health indicators during this period. The experimental block, however, showed larger gains on many indicators, which helped to bridge the initial gaps between the two blocks.

Of the three roles envisaged, committees performed two roles remarkably well: 1) undertaking activities to create awareness about health, and 2) fostering trust and understanding between the community and health staff. They largely failed at their third role, namely assessing people's health needs and developing activity plans. One main reason for this failure was that health workers did not think that committee members could help them with this technical task. Instead, they agreed to share survey findings with committee members and to suggest activities based on the findings. Committee members also held ideas about health planning that were contrary to those envisioned under the reproductive and child health program. They wanted to make services accessible to the very poor, or to find ways to give them free medicines. Based on those ideas, some committees did try "pro-poor" planning, which turned out to be a different exercise than participating in the micro-planning exercise.

One positive aspect of this model was that it allowed the two partners, committee members and health staff, to play their respective roles instead of controlling or competing with each other. The committees' roles were to organize health activities, which they did with support from health staff. Health staff also realized that their fieldwork became easier if they cooperated with committee members. However, neither could demand support from each other; they earned it through good working relationships and mutual respect. As a result, most committees tried to please health staff. Health staff also responded positively to committees that respected them and treated them well.

In the process, health committees created a certain level of social capital by collaborating with health staff and indirectly pressuring them to provide better quality services. This project proved that the community could exert pressure on service providers by actively participating in the service delivery process and by providing them with support.

Community Involvement in Reproductive Health: Findings from Research in Karnataka, India 
To sustain and scale up this model within the existing structures, however, will require the government to accept health committees as legitimate local institutions. Committees would not have the power to control health staff, nor would health staff treat committee members like village health workers. Neither of these positions would help committees assume the collaborative role that they have been playing so effectively. To help them retain their current role, they need to link with other existing committee structures in the state, such as the Rogi Kalyan Samithi or Board of Health Visitors, that represent both civil society and health officials and undertake the function of overseeing health institutions at district and block levels. A field test needs to be conducted to determine if this layered structure could execute the tasks previously performed by community facilitators and the FRHS that are needed to sustain and scale up the model to the district level. 


\section{REFERENCES}

1. Measham, A.R. and R.A. Heaver. 1996. India's Family Welfare Program: Moving to a Reproductive and Child Health Approach. The World Bank, Washington D.C.

2. Kumar, R. 2002. "Gender in reproductive and child health policy." Economic and Political Weekly, 37(32): 3369-3377.

3. Government of India. 1998. Manual on Community Needs Assessment Approach. Department of Family Welfare, Ministry of Health and Family Welfare, New Delhi, India.

4. The Futures Group International. 2001. Review of Implementation of Community Needs Assessment: Approach for Family Welfare in India. Policy Project II, New Delhi, India.

5. Kalway, K. and M. Rawat. 1999. "Family Welfare Programme in MP after ICPD: A Case Study," in Community Needs-based Reproductive and Child Health in IndiaProgress and Constraints. Health Watch Trust, Jaipur, India.

6. Bondurant, T. 1997, “The introduction of the target free approach in West Bengal: a case study," paper presented at the National Workshop on the Performance of Family Welfare Programme under Target Free Approach, Lucknow Uttar Pradesh, 24-25 November.

7. Sahany, A. 1990. Community Participation in Health and Family Welfare: Innovative Experiences in India, Indian Society of Health Administrators, Bangalore, India.

8. Mohankumar, S. 2002. "From people's plan to plan sans people," Economic and Political Weekly, 37(16): 1492-1497.

9. Panchayat Raj Update. 2002. 9(6), June.

10. International Institute for Population Sciences. Reproductive and Child Health Project, Rapid Household Survey (Phase I and II), 1998-99, Deonar, Mumbai, India. 


\section{Appendix 1: Register of Poor Families Data}

1. Name of the head of the household

2. Number of women 15- 49 years of age

3. Number of children by sex and age groups

4. Did anyone in the household have difficulty during pregnancy/delivery in the past year?

5. Have there been any episodes of measles in the past year among children in the household?

6. How many episodes of diarrhoea were there in the past year among children under 5 years of age in this household?

7. How many episodes of pneumonia were there in the past year among children under 5 years of age in this household?

8. Do children under 5 years of age in the household go to the nutrition programme?

9. How many of the children under 5 years of age in the household are malnourished?

10. How many children from this household go to school?

11. How many people in this household are suffering from night blindness?

12. How many episodes of malaria were there in the past year in this household?

13. How many people in this household are suffering from TB?

14. How many people in this household are suffering from skin problems?

15. How many people in this household have cataract?

16. Does the family have the RTI/STI card?

17. Are there any disabled children in this household?

18. What colour Below Poverty Line card does the household have?

19. How many people in the household are above 60 years of age?

20. How many of them get old age pension? 


\section{Appendix 2: Annual Plan of Thattekere Committee (2002- 2003)}

Members from different villages met separately to identify the poor families in their areas and used the names listed in the CNAA register as a reference. They then met together to discuss the combined list.

Of the total 740 households, they had identified 104 as "poor." Most of the poor lived in huts and were coolie workers. A few families in the poor category included only elderly people and no younger wage-earning member. In the meeting, the community facilitator discussed possible ways of collecting information about health problems and existing access to health services. He said they could collect information from the health workers' or anganwadi (nutrition program) workers' registers or visit the poor families and compile the data. Members preferred to do the latter so that they had firsthand information themselves. The community facilitator then explained the various columns in the poor household register. The committee covered three villages and all members in the committee could read and write. Of the 18 members, four members assumed responsibility for visiting poor families in their respective villages. The first time they visited, the community facilitator accompanied them. Two volunteers from Kalika Kendra also helped them with the visits.

Six people visited the 104 poor families in one day. They met three days later and compiled the information. They found that of the 38 children under 5 years of age, 22 were malnourished, seven had experienced measles, and 11 had suffered from repeated episodes of diarrhoea. Of the 22 malnourished children, 11 lived in a village where there was no anganawadi. There were also six elderly persons identified with cataracts. Based on these problems, the Thattekere committee decided to carry out the following actions over the next year especially for the poor families:

- Conduct child-weighing sessions every alternate month in the village where there is no anganwadi and give information on low-cost nutritious recipes

- Conduct awareness program regarding diarrhoea control and management and distribute ORS packets to poor families

- Increase mothers' awareness about the importance of measles vaccines

- Ensure that all six elderly people with cataracts be operated on free of charge

The CNAA data also indicated that institutional deliveries, use of spacing methods, and awareness about RTI/STIs was low. As a result, the committee planned several activities:

- An awareness with service camp about RTI/STI

- An awareness program for pregnant women and newlywed couples

The committee will ensure participation from poor families.

Community Involvement in Reproductive Health:

Findings from Research in Karnataka, India 